\title{
Intensification of Symbiotic Performances of Grain Legumes and Rhizobia through Joint Use of Agro-inputs: Review
}

\author{
Mnalku A. \\ Ethiopian Institute of Agricultural Research, Biological and Organic Soil Fertility Management Research \\ Program, Holeta, Ethiopia, P.O.Box: 2003
}

\begin{abstract}
As it holds in sub-Saharan Africa, low grain legume crop productivity has been facing Ethiopia and is often associated with reduced $\mathrm{N}_{2}$-fixation. For low-input users, symbiotic nitrogen fixation (SNF) can be an affordable, feasible and sustainable option particularly when employed in appropriate inoculation of effective rhizobial strains to improve the productivity of legumes. Here, we review past research interventions on agro-inputs and Rhizobiumlegume symbiosis interaction with a view of understanding the consequence on productivity of the symbiosis. First of all, information on farm-based need-to-inoculate and reinoculate legumes with rhizobia remain fundamental when benefit-oriented inoculation is thought. In addition, co-application of nutrients like phosphorus (P) or Sulphur (S), organic amendments, plant growth promoting microbes (PGPMs), arbuscular mycorrhizal fungi (AMF) and lime highly complemented rhizobia in enhancing symbiotic effectiveness. Sole lime application appeared no to improve yield of legumes, its co-application with rhizobia, acid tolerant variety and P fertilizer enhanced nitrogen $(\mathrm{N})$ and grain yield of legumes. The reaction of rhizobia and symbiosis to seed-dresser pesticides may be detrimental or beneficial (indirectly) depending on the rate, and type of the pesticide and the legume. Thus, co-application of rhizobial strains and agro-inputs generally enhanced the productivity of rhizobiallegume symbiosis, but this should be done with prior refining through context-based scientific research.
\end{abstract}

Key words: Agro-input, Inoculation, Nodulation, Rhizobia, Symbiotic Effectiveness

DOI: $10.7176 / \mathrm{JBAH} / 10-19-01$

Publication date:October $31^{\text {st }} 2020$

\section{Introduction}

In Ethiopia grain legumes (GLs) which rank second in area coverage, production, and grain yield next to cereals, are mostly grown by private peasant holdings under rain-fed condition [1]. Cool season grain legumes such as faba bean, chickpea lentil, field pea and warm season grain legumes such as soybean, common bean, groundnut, mung bean collectively account about 13 percent of the total arable land. However, cool season grain legumes comprise area and production share of 74.4 and $77 \%$ of the total grain legume production, respectively [1]. GLs are priceless crops in terms of improving food-feed and nutrition security, income benefit, and soil fertility of the smallholder farmer's livelihoods as well as environmental safety and economic gross domestic product (GDP) growth at national level [2]. However, limited usage of modern agronomic practices in optimum integration with crop protection, nutrient management and improved variety technologies have made the productivity below the demonstrated potential in Ethiopia. About 2 and 1.4 ton of average pulse grain yield increments were reported in research and on-farm fields as compared to the national average of 2012 cropping season, respectively [3].

One amazing feature of the legumes is their endowment of bioavailable $\mathrm{N}$ production in association with rhizobia called SNF. GLs were estimated to fix $60-80 \%$ of their N requirement from the atmosphere [4] despite the different rates reports by different researchers. Manipulation to improve this SNF would increase plant-based protein for human consumption, increase growth and yield of subsequent crops, and reduce synthetic $\mathrm{N}$ fertilizer use, which highly benefits the low-input farmers. Thus, inoculating the seeds with effective rhizobial strains could be considered as practical, low cost strategy to improve SNF efficiency or grain yield [5, 6, and 7]. For this reason, rhizobia inoculants are commercialized for more than 100 years across the world and for over two decades in Ethiopia.

Despite inoculating legumes with rhizobia often display substantial improvement in nodulation, yield and soil $\mathrm{N}$, the rate of improvements can be tremendously affected by the rate and method of organic, inorganic and biological agro-inputs or supplies application in the farm [8 and 9]. Several research results have been reported with regards to the interaction of variety of agro-inputs in the last five decades in Ethiopia or abroad. Hence, the general objective of this paper is to review the available research findings on rhizobia - agro-input combined applications with respect to grain yield improvement of GLs.

\section{Need to inoculate and alternately inoculate legumes on field base}

In relation to its relatively low current price and high cost of tests, farmers are often advised to use rhizobial biofertilizers in blanket particularly in most Sub-Saharan African countries. In this regard, spontaneous inoculation of legumes on farms that had no the target legume for at least five successive years was noted by [10]. Deciding whether to inoculate GLs or not, however, need to be relied on demonstrations on experimental plots. This is 
because the likelihood of yield response from inoculation would be higher when population of effective rhizobia is less than 20-50 cells g ${ }^{-1}$ soil [11]. Inoculation of high numbers of effective rhizobia to is quite essential to outcompete populations of ineffective rhizobia in the soil or build up populations that can survive limiting soil conditions [12].

The question of "how frequent a farmer need to inoculate his legume to grow on same farm?" is an important concern. The phenomenon is referred to as "alternate inoculation" and has been one of the key aspect of inoculation technology that has not yet received adequate attention by research. Rhizobia were reported to survive for over 30 years even in the complete absence its host-legume [13]. However, beyond survival, the stability of symbiotic effectiveness of inoculated strains is critical for agronomists [4]. This is because the maintenance of symbiotic effectiveness over the seasons will be predominantly constrained by the soil $\mathrm{pH}$, soil temperature, soil texture, and soil water content [10]. In view of this, study reports indicated that exemption of soybean inoculation up to the second or the third growing season did not compromised yield in comparison to the successively inoculation [14 and 15].

The status of soil nutrients, soil type and strain of rhizobia are dictating factors [4, and 15]. Clay dominated soils are generally believed to better for rhizobial survival as it may give refuge in the micropores of its aggregates [16] and offer protection against protozoal grazing [17]. It is thus essential to generate customized information on the persistence and effectiveness of strains in the field environment through several seasons [4 and 18] and this would be essential in Ethiopia where biophysical diversities are tremendous [19].

\section{Mineral nutrients and rhizobia improves SNF}

By its nature, the legume-rhizobia symbiosis imposes additional requirements of calcium $(\mathrm{Ca})$, potassium $(\mathrm{K}), \mathrm{P}$, boron $(\mathrm{B})$, zinc $(\mathrm{Zn})$, iron $(\mathrm{Fe})$, manganese $(\mathrm{Mn})$, cobalt $(\mathrm{Co})$, sulfur $(\mathrm{S})$ and molybdenum $(\mathrm{Mo})$ but $\mathrm{NO}_{3}-\mathrm{N}_{\text {apart }}$ from what is needed for plant growth and development [20]. Absolute or relative nutrient shortage or imbalance, thus, adversely affect nodulation or SNF [21]. Inhibition of nodulation or SNF by high soil $\mathrm{NO}_{3}-\mathrm{N}$ in all legumes is highlighted, despite its variance among species and cultivars [22]. On the other hand, legumes are generally regarded as efficient $\mathrm{P}$ utilizers due to soil phosphates solublization [23], finely branched root system [24], infection with mycorrhizae or adaptive growth to P limited condition like common bean [4]. However, they usually require more $\mathrm{P}$ than mineral $\mathrm{N}$-dependent plants [25] as nodules accumulate plenty of $\mathrm{P}$ and nodulation cause limited root development to capture $\mathrm{P}$ [26]. [27] reviewed the indispensable use of $20 \mathrm{~kg} \mathrm{P} \mathrm{ha}^{-1}$ for proper SNF in Ethiopian soils. The P requirements for SNF are still species or genotype dependent (Table 1).

Table 1. Grain yield response of GLs by rhizobial inoculant (RI) and mineral nutrient supplementations in Ethiopia

\begin{tabular}{|c|c|c|c|c|c|}
\hline Crop & Strain name** & Rate $\left(\mathrm{kg} \mathrm{ha}^{-1}\right)$ & Research site/condition & $\begin{array}{l}\text { Yield increase } \\
(\%)\end{array}$ & Reference \\
\hline \multirow[t]{8}{*}{ Soybean } & UK isolates & $0.023 \mathrm{Fe}$ & Shilile & 2.1 & \multirow[t]{2}{*}[28]{} \\
\hline & TAL-379 & $0.046 \mathrm{Fe}$ & Shilile & 6 & \\
\hline & MAR-1495 & $10 \mathrm{P}$ & Bako Tibe and Alaba & 4 & [29] \\
\hline & MAR-1495 & $10 \mathrm{P}$ & Kersa and Pawe & 6 & {$[30]$} \\
\hline & TAL-379 & $23 \mathrm{~N}$ & Finote Selam & 1 & [31] \\
\hline & Bradyrhizobia & $46 \mathrm{~N}$ & Jima & 29 & [32] \\
\hline & \multirow[t]{2}{*}{ MAR-1495 } & $30 \mathrm{~S}$ & \multirow[t]{2}{*}{ Assosa (potted soil) } & 39 (Belesa-95) & \multirow[t]{2}{*}[33]{} \\
\hline & & $40 \mathrm{~S}$ & & 46 (Wollo) & \\
\hline \multirow[t]{7}{*}{ Faba bean } & \multirow{2}{*}{$\begin{array}{l}\text { Inherent } \\
\text { rhizobia }\end{array}$} & $60 \mathrm{P}$ & \multirow[t]{2}{*}{ Mekele (potted soil) } & 134 & \multirow[t]{2}{*}[34]{} \\
\hline & & $15 \mathrm{Zn}$ & & $29(\mathrm{~ns})$ & \\
\hline & \multirow[t]{2}{*}{ "Local strain" } & \multirow[t]{2}{*}{$23 \mathrm{~N}+20 \mathrm{P}$} & Yield depleted soil & 43 & \multirow[t]{2}{*}[35]{} \\
\hline & & & Yield sustained soil & 7 & \\
\hline & FB-1035 & $10 \mathrm{P}$ & $\begin{array}{l}\text { Agarfa, Farta, Sinana, } \\
\text { Yimana densa }\end{array}$ & 13 & {$[29]$} \\
\hline & EAL-110 & $40 \mathrm{P}+15 \mathrm{Zn}$ & Melkasa & 24 & {$[36]$} \\
\hline & NM & $60 \mathrm{P}+30 \mathrm{~K}$ & $\begin{array}{l}\text { Werabe (potted soil)-shoot } \\
\text { dry mass }\end{array}$ & 60.5 & {$[37]$} \\
\hline \multirow[t]{5}{*}{$\begin{array}{l}\text { Common } \\
\text { bean }\end{array}$} & \multirow[t]{2}{*}{ HUPvR-16 } & $100 \mathrm{~N}$ & $\begin{array}{l}\text { Babile and Fedis (low rhizo } \\
\text { population) }\end{array}$ & 14 & \multirow[t]{2}{*}[38]{} \\
\hline & & $20 \mathrm{~N}$ & $\begin{array}{l}\text { Hirna (high rhizo } \\
\text { population }\end{array}$ & 2 & \\
\hline & HB-429 & $10 \mathrm{P}$ & $\begin{array}{l}\text { Sodo, Shalla, Dibate, } \\
\text { Alaba, Bakotibe }\end{array}$ & 10 & {$[29]$} \\
\hline & \multirow[t]{2}{*}{ Phaseoli } & $10 \mathrm{P}$ & Melkasa & $10(\mathrm{~ns})$ & \multirow[t]{2}{*}{ [39] } \\
\hline & & $40 \mathrm{P}$ & Melkasa & $39(\mathrm{~ns})$ & \\
\hline
\end{tabular}




\begin{tabular}{|c|c|c|c|c|c|}
\hline Crop & Strain name** & Rate $\left(\mathrm{kg} \mathrm{ha}^{-1}\right)$ & Research site/condition & $\begin{array}{l}\text { Yield increase } \\
(\%)\end{array}$ & Reference \\
\hline \multirow[t]{5}{*}{ Chickpea } & \multirow[t]{4}{*}{ CP-029 } & $10 \mathrm{P}$ & $\begin{array}{l}\text { Ada'a, Gimbichu, Demote } \\
\text { Dale and Ginir }\end{array}$ & 8 & [29] \\
\hline & & \multirow[t]{3}{*}{$23 \mathrm{P}$} & Ginir & 15 & \multirow[t]{3}{*}{ [40] } \\
\hline & & & Damote gale & 13 & \\
\hline & & & Ada'a & 8 & \\
\hline & CP-M41 & $30 \mathrm{~S}$ & Gondar Zuria & 25 & [41] \\
\hline
\end{tabular}

$\mathrm{NN}=$ not mentioned; $* *=$ Strain names are given by the researcher and often composed of the abbreviation of the institute and/or host legume, and followed by a number to indicate its history in the collection; ns = non-significant; $\mathrm{Zn}=$ Zinc; $\mathrm{K}=$ potassium; $\mathrm{Fe}=$ iron

The grain yield effect of RI with different nutrients namely Fe, P, N, S, Zn and K were tested on four GLs species (Table 1). In comparison to the sole inoculant, nutrient supplementation to inoculants earned grain yield increase, despite the tremendous variations in magnitude (1-134\%). In fact such wide variation is expected as the studies were unharmonized and hence affected by factors of time, strain, location, even cultivars and sometimes rates with in a nutrient. Yield depleted (low-input farming systems) and low rhizobial population sites had significant increases for particularly $\mathrm{N}$ and $\mathrm{P}$. The outputs listed hereunder except $\mathrm{N}$ and $\mathrm{P}$ are just observations that indicate the possibilities of response but are not final recommendations. Further validation of the promising treatments in integrated manner at on-farm condition and analyzing both the agronomic and the associated marginal rate of return would help reach to the ultimate verified output.

\section{Effect of organic fertilizers on rhizobia-legumes symbiosis}

Research reports from Ethiopia confirmed that co-application of rhizobia and compost showed about 23, 46 and $82 \%$ grain yield increments of faba bean over the sole RI at Haramaya, Lay Gayint and Kulumsa locations, respectively (Table 2). These relative increments are notable but still lower than the 97\% soybean seed yield increase following rhizobia and 10 ton $\mathrm{ha}^{-1}$ vermicompost co-application over the non-composted and noninoculated treatment reported by [42]. The nodulation and SNF capacity of cowpea also remained unchanged under 6 ton $\mathrm{ha}^{-1}$ vermicompost as reported by [43]. Besides, higher average nodule number per plant was reported from plants of different legume species treated with manure in relative to the control [44]. [45] also noted that soybean nodulation and SNF in low fertility soils would not be suppressed by organic amendments like vermicompost up to $148 \mathrm{~kg} \mathrm{~N} \mathrm{ha}^{-1}$. The slow $\mathrm{N}$ release, plant growth promotion and nutrient uptake enhancement, phosphorous contribution effects [46 and 44] as well as substrate function for rhizobia in the early infection periods would attribute to the synergy as compared to inorganic sources $\mathrm{N}$.

\section{Effect of agro-chemicals on rhizobia-legume symbiosis}

Pesticides and rhizobia seed treatments are cheap insurances against seed and soil-borne pathogens, and nitrogen deficiency of pulses, respectively [47]. However, thier compatibility during joint use on pulse seeds remained controversial in the literature predominantly due to variation in methods and the lack of quantitative data [48]. Rhizobial survival reduction, poor symbiosis or poor legume performance were mentioned as major manifestations of their antagonistic effect and predominantly associated to concentration of pesticides [49].

In contrast, [50] noted the presence of compatibility potential between pesticides and RI. However, the experimental conditions [51], soil [52], strain type and climate [53], host [54], pesticide (type, concentration and time of dressing) [55] and climate determine the degree and nature of compatibility. Several studies have been made with regards to optimizing compatibility. Co-application of Mesorhizobium species with apron and imidalm at potted soil gave 6 and 10\% chickpea shoot dry weight increment over the sole inoculated treatment. Whereas at field condition, apron and mancozeb earned 9 and 2\% faba bean grain yield increment over the sole RI at Ginchi, Ethiopia (Table 2). These outputs demonstrated that not only the rate and type of the fungicide but also the sequence of dressing would have minimized the ill effects on the inoculant (Figure 1). The figure demonstrated that co-application of RI and Thiram affected both nodulation and fresh biomass of chickpea in similar trend. In terms of the degree of reduction in both parameters, Thiram then RI $<$ RI then Thiram $<$ RI + Thiram. It is also essential to note that rhizobia appeared to be more susceptible to fungicide at in vitro than field condition [51]. In view of this, gonotobiotic research outputs would not essentially help to predict the fate of fungicide and RI at field condition. 


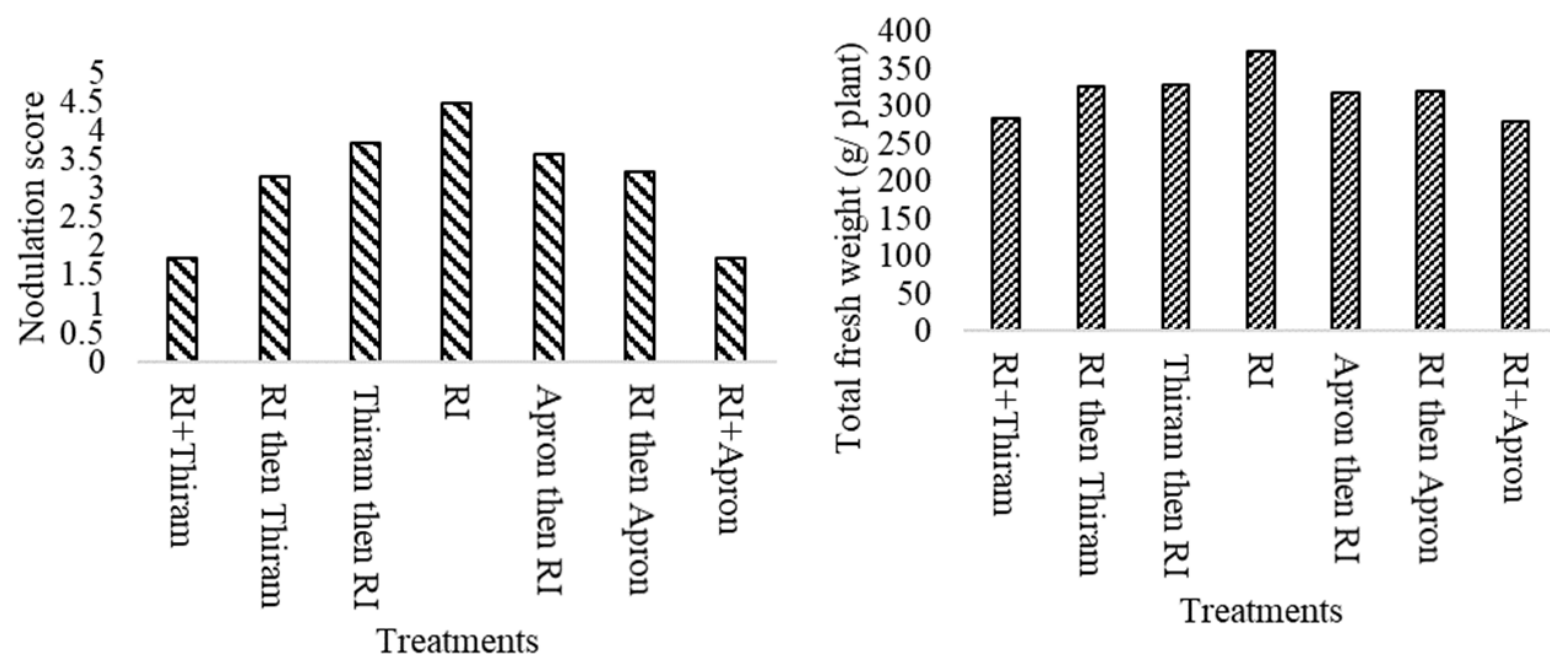

Figure 1. Effects of fungicide seed dressings on nodule score (left) and total fresh weight (right) in chickpeas adapted from [56]. (Hint: RI + Thiram= simultaneous dressing; apron then RI= sequential dressing)

\section{Co-inoculation of RI and PGPMs}

There have been an increasing number of reports on the co-inoculation of rhizobia with other plant growth promoting microbes (PGPMs) [57] or arbuscular micorrhizal fungi (AMF), enhancing a variety of legumerhizobia symbioses in variety of synergistic mechanisms. About 40,19 and $28 \%$ grain yield increments were reported on common bean, soybean and chickpea due to AMF and rhizobia co-inoculation, respectively $[58,59$ and 60] though constraints of inoculant production are prevailing [4]. However, neither sole AMF nor coinoculation with RI field test reports are available in cereal or legumes in Ethiopia. On the other hand, plant growth promoting rhizobacteria (PGPR) guaranteed significant improvement in the symbiotic effectiveness of RI on common bean, lentil and cowpea [43 and 61]. Field-level co-inoculation of Mesorhizobium ciceri (RC3) + Bacillus (PSB10) + Azotobacter chroococcum (A4) also improved seed yield of chickpea by $250 \%$ [62].

Isolation and effectiveness tastings of PGPMs are undergoing in different institutions of Ethiopia such as Addis Ababa University and Ethiopian Institute of Agricultural Research. Among these, the PGPMs test on teff crop at Debre Zeit during 2019 (Personal communication) was remarkably promising. As mentioned in table 2, [63 and 64] also reported encouraging synergy between RI and PGPMs, which showed about 36 and 6\% grain yield increments over the uninoculated control on soybean and field pea at Assosa and Sinana, Ethiopia, respectively. The difference in the strains of rhizobia and phosphate solubilizing used as well as the site biophysical conditions were believed to contribute for the response variation. In general, selecting efficient and compatible rhizobia, AMF and PGPM strains is likely to potentially improve legumes or cereals productivity in low input farming systems or less fertile soil conditions in Ethiopia.

Table 2. Symbiotic performance of RIs in response to co-application with different farm-inputs

\begin{tabular}{|c|c|c|c|c|}
\hline Crop & $\begin{array}{l}\text { Experimental condition } \\
\text { (site) }\end{array}$ & Co-applied inputs & $\begin{array}{l}\text { Yield increase } \\
(\%)\end{array}$ & Reference \\
\hline \multirow[t]{2}{*}{ Soybean } & Field (Assosa) & $\begin{array}{l}\text { TAL-378 (RI) } \\
\text { (Pseudomonas) }\end{array}$ & $\begin{array}{lr}36 & \text { (over non } \\
\text { inoculated) }\end{array}$ & [63] \\
\hline & Field (Jima) & Bradyrhizobia + lime & 30 (over sole RI) & [32] \\
\hline \multirow[t]{6}{*}{$\begin{array}{l}\text { Faba } \\
\text { bean }\end{array}$} & Field (Haramaya) & $\begin{array}{lcccc}\text { HUFBR15 } & (\mathrm{RI}) & + & 8 & \text { ton } \\
\text { vermicompost } & (1.31 \% \mathrm{~N}) & \mathrm{ha}^{-1} & \\
\end{array}$ & 23(over sole RI) & [65] \\
\hline & Field (Lay Gayint) & $\begin{array}{l}\text { EAL-110 (RI) }+3.6 \text { ton lime }+30 \mathrm{~kg} \\
\mathrm{P} \mathrm{ha}^{-1}+8 \text { ton compost }(0.81 \% \mathrm{~N})\end{array}$ & 46 & [66] \\
\hline & Green house (Sand) & $\begin{array}{l}\text { AWUR8 (RI) }+0.2 \mathrm{~mL} \text { glyphosate } \\
+0.15 \mathrm{~g} \text { mancozeb }\end{array}$ & $\begin{array}{l}7 \text { (increase in } \\
\text { SDW over the } \\
\text { sole RI) }\end{array}$ & [67] \\
\hline & Field (Kulumsa) & $\begin{array}{l}\text { EAL-110 + } 9 \mathrm{~kg} \mathrm{~N} \quad\left(6.2 \text { ton } \mathrm{ha}^{-1}\right. \\
\text { vermicompost }\end{array}$ & $\begin{array}{l}82 \text { (over } \\
\text { uninoculated) }\end{array}$ & [68] \\
\hline & \multirow[t]{2}{*}{ Field (Holeta) } & FB-1017(RI) + apron & 9 (under sole RI) & \multirow[t]{2}{*}{ [9] } \\
\hline & & FB-1035(RI) + mancozeb & 2 (under sole RI) & \\
\hline \multirow[t]{2}{*}{ Field pea } & Field (Sinana) & EAL-302 (RI) + PSB (Bacillus) & $\begin{array}{l}>3(\text { over } 8 / 20 \mathrm{~kg} \\
\text { NP ha- }\end{array}$ & [64] \\
\hline & Field (Gedo) & $23 / 25 \mathrm{~kg} \mathrm{NP} / \mathrm{ha}+6$ ton lime $\mathrm{ha}^{-1}$ & & [69] \\
\hline
\end{tabular}




\begin{tabular}{|l|l|l|l|l|}
\hline Crop & $\begin{array}{l}\text { Experimental condition } \\
(\text { site })\end{array}$ & Co-applied inputs & $\begin{array}{l}\text { Yield increase } \\
(\%)\end{array}$ & Reference \\
\hline Chickpea & Green house (potted soil) & CP-029 (RI) + apron & $\begin{array}{l}6 \text { (under sole I), } \\
\text { SDW }\end{array}$ & [9] \\
\cline { 3 - 4 } & & CP-029 (RI) + imidalm & $\begin{array}{l}10 \text { (under sole I), } \\
\text { SDW }\end{array}$ & \\
\hline
\end{tabular}

$\mathrm{SDW}=$ shoot dry weight $\mathrm{PSB}=$ phosphate solubilizing bacteria

Initiatives that promote rhizobia inoculation in legume production in Sub Saharan Africa generally advise the use of balanced nutrients [70]. Though nitrate N generally inhibits SNF [71], application of micro-dose or starter $\mathrm{N}$ was found to be important to enhance SNF particularly in low $\mathrm{N}$ soils [72].

\section{Compatibility of RI with liming}

[73] estimated that close to $28.1 \%$ of the Ethiopian cultivated land is strongly acidified ( $\mathrm{pH} 4.1-5.5)$. Such strong soil acidity highly has been constraining the production of GLs in the highlands of Ethiopia [32]. The common mechanisms are deterring survival, persistence and nodulation rhizobia, limiting SNF and stunting the growth and development of the crops are supposed to be its primary manifestations [74 and 75]. Beyond the low $\mathrm{pH}$, aluminum and manganese toxicity, and $\mathrm{P}, \mathrm{Ca}, \mathrm{Mg}$ and Mo deficiency are the underlying factors [76].

Managing the deleterious effects of soil acidification through liming has long been shown to improve crop yield [77]. It is a common means of raising soil $\mathrm{pH}$, which leads to greater activities of soil bacteria [78 and 79]. These activities will ultimately insure increased soil organic matter decomposition and nutrient cycling and $\mathrm{Ca}^{2+}$ supply [80 and 81]. However, yield increments in response to liming will not be always positive mostly due to deficiency of nutrients like P [82]. [83] also noted the negative effect of long-term use of lime on the abundance and diversity, and community structure of diazotrophs.

Integration of liming, tolerant host tolerant RI [84 and 85] and nutrients like P [86] will be highly essential to sustainably mitigate the poor productivity of GLs in highly acidic soils of Ethiopia [76]. In view of this, [87] demonstrated the improvement of SNF of cowpea by $16 \%$ through combined use of RI + lime $+\mathrm{P}$ compared to the un-inoculated treatment. Similarly, the use of lime (6 ton $\left.\mathrm{ha}^{-1}\right)$ with Bradyrhizobium inoculation tangibly improved soybean grain yield by $30 \%$ in Jima area, Ethiopia [32]. [88] also reported a significant interaction effects of Rhizobium, Mo and lime on common bean in South Africa. In contrast, [86] reported the absence of nodulation improvement of cowpea in Sao Luis, Brazil via dual use of lime and inoculants.

\section{Rhizobia potential as biocontrol agent}

The plant growth promotion effect of rhizobia through SNF, nutrient solublization and phytohormone production and indirectly via pathogen growth inhibition is well documented. Other than that, there is growing evidence that rhizobia can also act as protective agents against microbial pathogens [89]. The disease suppression effects were hypothesized to be enhanced when two or more rhizobial strains are combined [90]. In this regard, [91] obtained $73 \%$ faba bean black root rot severity reduction by using composite of four rhizobial isolates at greenhouse level. In addition, sole application of Bradyrhizobium japonicum at field improved soybean germination by $67 \%$ and reduced Fusarium solani-induced foliage and root rot disease severity in 118 and 75\%, respectively [92]. Besides, application of rhizobia significantly suppressed root rot fungi and root knot nematode of GLs [93].

Two remarkable points were noted in [94] from their Rhizobium etli inoculated common bean study against the virulent strain Pseudomonas syringae pv. Phaseolicola: its transgenerational (expressed down the offspring) property and non-significant reduction on symbiotic properties such as nodulation and nitrogenase activities. The later finding would give relief for the worry of agronomists that biocontrol role of rhizobia would not significant compromise SNF. The mechanisms by which the rhizobia prevent growth and development of pathogens are antagonism (production of lytic enzymes), competitive exclusion, antibiotic production, signal interference, competition for nutrients ( $\mathrm{N}$ or $\mathrm{Fe}$ ), hormone production, and activation of the induced systemic resistance (ISR) [95].

\section{CONCLUSION}

The use of Rhizobium inoculants for improvement in SNF and productivity of grain legumes has been practiced for over a century in the world and over 2 decades in Ethiopia. In those times, quite effective strains have been selected and verified for a range of GLs and use protocols have been developed. Beyond the symbionts, rhizobia survival and the symbiosis effectiveness in response to organic, inorganic and biological agro-inputs have been researched in detail. In most cases, co-application of mineral nutrients such as $\mathrm{P}, \mathrm{N}, \mathrm{Mo}, \mathrm{S}$, and Fe; organic fertilizers, lime and PGPMs showed positive effect on rhizobia multiplication, proper growth of the host legume, and SNF and productivity of the system. The function of inputs like lime in case of acidic soil $(\mathrm{pH}<5.5)$ and $\mathrm{P}$ in most tropical soils remained to be fundamental. But, the co-application of lime and $\mathrm{P}$ tended to be an essential practice. In other hands, the PGPMs and organic fertilizer inputs were appeared to enhance symbiotic efficiency. 
Though it requires context-specific observation8, the compatibility of agrochemicals and rhizobia is not always detrimental. SNF-neutral responses have been reported from several studies. Whether or not to inoculate and grow same legume species on same farm in each rotation cycle is important issue and seeks crop and situation specific research recommendations. Thus, rhizobia-legume symbiosis productivity could be enhanced sustainably through deliberate and test-based combination of agro-inputs.

\section{References}

1. CSA (Central Statistical Agency of Ethiopia) (2016). Agricultural sample surveys 2015/2016. Report on area and production of major crops (private peasant holdings, Meher season), Volume 1. $14 \mathrm{p}$.

2. Rashid S, Yirga C, Behute B, Lemma S (2010). Pulses value chain in Ethiopia: Constraints and opportunities for enhancing exports: International Food Policy Research Institute (IFPRI). Working paper. pp. 2-18.

3. Atnaf M, Tesfaye K, Dagne K (2015). The importance of legumes in the Ethiopian farming system and overall economy: An overview. AJEA 7(6): 347-358.

4. Giller KE (2001). Nitrogen fixation in tropical cropping systems, $2^{\text {nd }}$ ed., CABI Publishing, Wallingford, Oxford. pp. 140-297.

5. Argaw A, Mnalku A (2017b). Symbiotic effectiveness of Rhizobium leguminosarum bv. vicieae isolated from major highland pulses on field pea (Pisum sativum L.) in soil with abundant rhizobial population. Annals of Agrarian Science 15: 410-419.

6. Argaw A, Mnalku A (2017c). Effectiveness of native Rhizobium on nodulation and yield of faba bean (Vicia faba L.) in Eastern Ethiopia. Archives of Agronomy and Soil Science 63(10): 1390-1403.

7. Mnalku A, Mitiku G (2019). Response of chickpea (Cicer arietinum L.) to indigenous rhizobial isolates inoculation on Vertisols of Central Ethiopian Highland. Ethiop. J. Agri. Sci. 29 (2): 109-117.

8. Thilakarathna MS, Chapagain T, Ghimire B, Pudasaini R, Tamang BB, Gurung K, Choi K, Rai L, Magar S, Bishnu BK, Gaire S, Raizada MN (2020). Evaluating the effectiveness of Rhizobium inoculants and micronutrients as technologies for Nepalese common bean smallholder farmers in the real-world context of highly variable hillside environments and indigenous farming practices. Agriculture. 9 (20).

9. Mnalku A, Mitiku G (2020). Compatibility of agrochemicals with rhizobial inoculants during co-application on chickpea (Cicer ariethinum) and faba bean (Vicia faba L.) at Welmera District, Holeta. Presented on Research Workshop of January 3-5, 2020. Addis Ababa, Ethiopia.

10. Abendroth L, Elmore R, Ferguson RB (2006). G06-1622 Soybean inoculation: applying the fact to your fields (part two of a two part series). Historical materials from University of Nebraska-Lincon Extension. Paper 2077. Available at: http://digital commons.unl.edu/extensionhist/2077.

11. Thies JE, Singleton PW, Bohlool BB (1991a). Influence of the size of indigenous rhizobial populations on establishment and symbiotic performance of introduced rhizobia on field-grown legumes. Applied and Environmental Microbiology 57: 19-28.

12. Deaker R, Roughley RJ, Kennedy IR (2004). Legume seed inoculation technology — a review. Soil Biology and Biochemistry 36: 1275-1288.

13. Mårtensson AM, Witter E (1990). Influence of various soil amendments on nitrogen fixing soil microorganisms in a long-term field experiment, with special reference to sewage sludge. Soil Biology and Biochemistry 22: 977-982.

14. Saint Macary H, Beunard P, Scaglia JA, Hakizimana A, Pandzou J (1992). Inoculation des légumineuses en milieu tropical: recherche-développement et aspects économiques. In: Mulongoy, K., Gueye, M. and Spencer, D.S.C. (eds) Biological Nitrogen Fixation and Sustainability of Tropical Agriculture. Wiley/Sayce, London, pp. 343-350.

15. Anderson E (2014). Need for seed re-inoculation in Swedish soybean cropping sequences. An MSc Thesis. SLU. 32 p. Available at http://stud.epsilon.slu.se.

16. Heijnen CE, Hok-A-Hin CH, van Veen JA (1991). Protection of Rhizobium by bentonite clay against predation by flagellates in liquid cultures. FEMS Microbiology Ecology 85: 65-72.

17. Danso SK, Keya SO, Alexander M (1975). Protozoa and the decline of Rhizobium populations added to soil. Canadian Journal of Microbiology 21: 884-895.

18. Yates RJ, Abaidoo R, Howieson JG (2016a). Field experiments with rhizobia. In: Howieson, J.G. \& Dilworth, M. J. (eds.), Working with rhizobia. Canberra: Australian Centre for International Agricultural Research, Canberra. pp. 145-154.

19. Fikre A, Funga A, Korbu L, Eshete M, Girma N, Zewdie A, Bekele D, Muhamed R, Daba K, Ojiewo C (2018). Stability analysis in chickpea genotype sets as tool for breeding germplasm structuring strategy and adaptability scoping. Ethiop. J. Crop Sci. Vol. 6 (Special Issue) No. 2.

20. O'Hara GW (2001). Nutritional constraints on root nodule bacteria affecting symbiotic nitrogen fixation: A review. Aust. J. Exp. Agric. 41: 417-433.

21. Valliyodan B, Nguyen HT (2008). Genomics of abiotic stress in soybean. In: Soybean Genomics, G. Stacey 
(Ed). Springer Verlag, New York. pp. 35-70

22. Argaw A, Mnalku A (2015). Inherent soil fertility as affected Rhizobium inoculation and inorganic $\mathrm{N}$ application effect on common bean. Ethiop. J. Agric. Sci. 26(1): 27- 48.

23. Nuruzzaman M, Lambers L, Bolland, MD, Veneklaas EJ (2005). Phosphorus uptake by grain legumes and subsequently grown wheat at different levels of residual phosphorus fertilizer. Australian Journal of Agricultural Research 56:1041-1047.

24. Jensen ES, Hauggaard-Nielsen $\mathrm{H}$ (2003). How can increased use of biological $\mathrm{N}_{2}$ fixation in agriculture benefit the environment? Plant and Soil 252: 177-186.

25. Serraj R, Adu-Gyamfi J (2004). Role of SNF in the improvement of legume productivity under stressed environments. West Afri. Jou. of Applied Ecology 6.

26. Cassman KG, Whitney AS, Stockinger KR (1980). Root growth and dry matter distribution of soybean as affected by P stress, nodulation and nitrogen source. Crop Science 20 (2): 239-240.

27. Mnalku A, Abera Y, Mitiku G (2016). Response of grain legumes to inorganic and biological fertilizers applications in Ethiopia: A Review. Ethiopian Journal of Natural Resources16 (1): 43-67.

28. Argaw A (2015). Iron requirement for soybean [Glycine max (L.) Merrill] inoculated with selected exotic and native isolates of Bradyrhizobium sp. under irrigated conditions. Archives of Agronomy and Soil Science 61(10): 1491-1509.

29. Belete S, Bezabih M, Abdulkadir B, Tolera A, Mekonnen K, Wolde-meskel E (2019). Inoculation and phosphorus fertilizer improve food-feed traits of grain legumes in mixed crop-livestock systems of Ethiopia. Agriculture, Ecosystems and Environment 279: 58-64.

30. Theresa Ampadu-Boakye, Esther Ronner, Fred Kanampiu, 2018, N2Africa Annual Report 2017, www.N2Africa.org, $71 \mathrm{pp}$.

31. Feyisa T, Amare T, Gebresilassie Y (2010). Effect of Bradyrhizobium japonicum on nodulation and grain yield of Soybean. In: Birru Yitaferu, Teshome Tesema, Zewudu Ayalew (eds). Proceedings of the 3rd Annual Regional Conference on Completed Research Activities on Soil and Water Management, Forestry, and Agricultural Mechanization, 1-4 September 2008, Amhara Region Agricultural Research Institute (ARARI), Bahir Dar, Ethiopia

32. Bekere W (2013). Liming effects on yield and yield attributes of nitrogen fertilizer and bradyrhizobia inoculated soybean grown in acidic soil at Jima, South Western Ethiopia. Journal of Biology, Agriculture and Healthcare 3(7).

33. Getachew Z, Abera G, Beyene S (2017). Rhizobium inoculation and sulphur fertilizer improved yield, nutrients uptake and protein quality of soybean (Glysine max L.) varieties on Nitisols of Assosa area, Western Ethiopia. Academic Journal 11(5):123-132.

34. Weldu Y, Habtegriel K (2013). Effect of zinc and phosphorus fertilizers application on nodulation and nutrient concentration of faba bean (Vicia faba L.) grown in calcaric Cambisol of semi-arid Northern Ethiopia. Academia Journal of Agricultural Research 1(11): 220-226.

35. Adamu A, Hailemariam A, Assefa F, Bekele E (2001). Studies of Rhizobium inoculation and fertilizer treatment on growth and production of faba bean (Vicia faba L.) in some 'Yield-Depleted' and 'YieldSustained' regions of Semen Shoa. SINET: Ethiop. J. Sci. 24(2):197-211.

36. Desta Y, Habtegebrial K, Weldu Y (2015). Inoculation, phosphrus and zinc fertilization effects on nodulation, yield and nutrient uptake of faba bean (Vicia faba L.) grown on calcarious cambisol of semiarid Ethiopia. Journal of Soil Science and Environmental Management 6(1):9-15.

37. Woldekiros B, Worku W, Abera G (2018). Response of faba bean (Vicia faba L.) to Rhizobium inoculation, phosphorus and potassium fertilizers application at Alicho Wuriro Highland, Ethiopia. Acad. Res. J. Agri. Sci. Res. 6(6): 343-350.

38. Argaw A, Tsigie A (2015). Indigenous rhizobia population influences the effectiveness of Rhizobium inoculation and need of inorganic $\mathrm{N}$ for common bean (Phaseolus vulgaris L.) production in eastern Ethiopia. Chem. Biol. Technol. Agric. 2:19.

39. Abdulkadir B (2006). Response of haricot bean (Phaseolus vulgaris L.) to nitrogen, phosphorus and inoculation of Rhizobium phaseoli at Melkassa. An MSc Thesis, Hawassa University. 98 p.

40. Wolde-meskel E, van Heerwaarden J, Abdulkadir B, Kassa S, Aliyi I, Degefu T, Wakweya K, Kanampiu F, Giller KE (2018). Additive yield response of chickpea (Cicer arietinum L.) to Rhizobium inoculation and phosphorus fertilizer across smallholder farms in Ethiopia. Agric., Ecosyst and Environ. 261:144-152.

41. Shewangizaw B (2017). Response of chickpea (Cicer aritienum L.) to sulphur and zinc nutrients application and Rhizobium inoculation in north western Ethiopia. An MSc thesis submitted to Haramaya University. pp.111.

42. Azarpour E, Moradi M, Bozorgi HR (2012). Effect of vermicompost application and seed inoculation with biological nitrogen fertilizer under different plant densities in soybean. African Journal of Agri. Res. 7(10): 1534-1541. 
43. Khan VM, Manohar KS, Verm HP (2015). Effect of vermicompost and biofertilizer on yield, quality and economics of cowpea. Ann. Agric. Res. New Series 36(3):309-311.

44. Otieno PE, Muthomi JW, Chemining'wa GN, Nderitu JH (2007). Effect of rhizobia inoculation, farmyard manure and nitrogen fertilizer on growth, nodulation and yield of selected food grain legumes. Afr. Crop. Sci. Soc. 8:305-312.

45. Mathengea C, Thuita M, Masso C, Gweyi-Onyango J, Vanlauw B (2019). Variability of soybean response to rhizobia inoculant, vermicompost, and a legume-specific fertilizer blend in Siaya County of Kenya Catherine. Soil and Tillage Research 194:1-12.

46. Nagavallema KP, Wani SP, Stephane L, Padmaja VV, Vanella C, Babu RM, Sahrawat KL (2004). Vermicomposting: Recycling wastes into valuable organic fertilizer. Global Theme on Agroecosystems Report no. 8. Patancheru 502 324, Andhra Pradesh, India, ICARDA. pp. 20.

47. Campo RJ, Araujo RS, Hungria M (2009). Nitrogen fixation with the soybean crop in Brazil: Compatibility between seed treatment with fungicides and bradyrhizobial inoculants. Symbiosis 48: 154-163.

48. Curley RL, Burton JC (2020). Compatibility of Rhizobium japonicum with chemical seed protectants. Agronomy journal 67 (6).

49. Ahemad M, Khan MS (2013). Pesticides as antagonists of rhizobia and the legume-Rhizobium symbiosis: A Paradigmatic and Mechanistic Outlook. Biochemistry and Molecular Biology 1(4):63-75.

50. Pereira CE, de Souuza FM, Oliveira JA, Caldiera CM (2010). Compatibility among fungicide treatments on soybean seeds through film coating and inoculation with Bradyrhizobium strains. Acta Scientiarum Agronomy 32 (4): 585-589.

51. Eberbach PL (2018). The effect of herbicides and fungicides on legume-Rhizobium symbiosis in J. Altman (Ed.), Pesticide interaction in crop production: benefitial and deleterious effects: CRC press. pp.183-212.

52. Castro S, Vinocur M, Permigian M (1997). Interaction of mancozeb and Rhizobium spp. in pure culture and under field condition. Biol Fertil soils 25:147-151.

53. Kutcher HR, Lafond G, Johnston AM, Miller PR, Gill KS, May WE (2002). Rhizobium inoculant and seedapplied fungicide effects on field pea production. Can. J. Plant. Sci. 82:645-661.

54. Mohamad R, Al-naser Z (2018). Effect of pesticides and essential oils in the growth of rhizobial isolated from nodules of some leguminous plants in vitro. The Arab Journal for Arid Environments (ACSAD) 1: 111-117.

55. Jinturkar BP (2017). Compatibility between groundnut Rhizobium and seed dressing fungicide. International Journal of Curr. Microbiol. App. Sci.6(5):1067-1075.

56. GRDC (2018). Chickpea planting. Section 3. Available at: https://grdc.com.au

57. Fox JE, Gulledge J, Engelhaupt E, Burow ME, McLachlan JA (2007). Pesticides reduce symbiotic efficiency of nitrogen-fixing rhizobia and host plants. PNAS 104 (2): 10282-10287.

58. Safapour M, Ardakani M, Khaghani S, Rejali F, Zargari K, Changizi M, Teimuri M (2011). Response of yield and yield components of three red bean (Phaseolus vulgaris L.). American-Eurasian J. Agr. Environ. Sci. 11:398-405.

59. Salih SH, Hamd SA, Dagash YMI (2015). The effects of Rhizobium, mycorrhizal inoculations and diammonium phosphate (DAP) on nodulation, growth, and yield of soybean. Univers. J. Agr. Res. 3: 11-14.

60. Rasaei B, Ghobadi ME, Nadjaphy A, Rasaei A (2012). The study effects of some biological agents on chickpea (Cicer arietinum L.) under semi-dry conditions in Kermanshah. Eur. J. Exp. Biol. 2: 1113-1118.

61. Korir H, Mungai NW, Thuita M, Hamba Y, Masso C (2017). Co-inoculation effect of rhizobia and plant growth promoting rhizobacteria on common bean growth in a low phosphorus soil. Front. Plant Sci. 8(141):1-10.

62. Wani PA, Khan MS, Zaidi A (2007). Co-inoculation of nitrogen fixing and phosphate solubilizing bacteria to promote growth, yield and nutrient uptake in chickpea. Acta Agron. Hung 55: 315-323.

63. Argaw A (2012). Evaluation of co-inoculation of Bradyrhizobium japonicum and phosphate solubilizing Pseudomonas spp. effect on soybean (Glycine max L. (Merr.)) in Assossa area. J. Agr. Sci. Tech.14: 213-224.

64. Abera Y, Pant LM, Hailemariam A (2008). Effects of dual inoculation of Rhizobium and phosphate solubilising bacteria on nodulation, yield and $\mathrm{N}$ and $\mathrm{P}$ uptake of field pea (Pisum sativum L.). Ethiopian Journal of Natural Resources 9(2):209-230.

65. Argaw A, Mnalku A (2017a). Vermicompost application as affected by Rhizobium inoculation on nodulation and yield of faba bean (Vicia faba L.). Ethiop. J. of Agric. Sci. 27 (2):17-29.

66. Fekadu E, Kibret K, Melese A, Bedadi B (2018). Yield of faba bean (Vicia faba L.) as affected by lime, mineral $\mathrm{P}$, farmyard manure, compost and Rhizobium in acid soil of Lay Gayint District, northwestern highlands of Ethiopia. Agric and Food Security 7:16.

67. Aynalem B, Assefa F (2017). Effect of glyphosate and mancozeb on the rhizobia isolated from nodules of Vicia faba L. and on their $\mathrm{N}_{2}$-fixation, North Showa, Amhara Regional State, Ethiopia. Advances in Biology 1-7 (Article ID 586459).

68. Admasu A, Tadesse K, Habte D, Mekonen A, Tadess A (2017). Integrated effect of vermicompost, rhizobia inoculation and NP fertilizer on yield of faba bean at Kulumsa in Arsi Zone Ethiopia. Asian Journal of Plant 
Science and Research 8(4):8-12.

69. Abera T, Abebe Z (2018). Effects of fertilizer, Rhizobium inoculation and lime rate on growth and yields field pea in Horro and Gedo highlands. Adv Crop Sci Tech 6: 397.

70. Ronner E, Franke AC, Vanlauwe B, Dianda M, Edeh E, Ukem B, Giller KE (2016). Understanding variability in soybean yield and response to P-fertilizer and Rhizobium inoculants on farmers' fields in northern Nigeria. Field Crop Res.186:133-145.

71. Zahran HH (1999). Rhizobium-legume symbiosis and nitrogen fixation under severe conditions and in an arid climate. Microbiol. Mol. Biol. Res. 63 (4):968-989.

72. Zerihun GG, Lijalem AD. (2020). Response of soybean to rhizobial inoculation and starter $\mathrm{N}$ fertilizer on Nitosols of Assosa and Begi areas, Western Ethiopia. Environmental Systems Research 9(14):1-11.

73. Haile H, Asefa S, Regassa A, Demssie W, Kassie K, Gebrie S (2017). Extension manual for acid soil management (unpublished report). Addis Ababa, Ethiopia.

74. Graham PH, Viteri SE, Mackie F, Vargas AT, Palacios A (1982). Variation in acid soil tolerance among strains of Rhizobium phaseoli. Field Crops Res. 5:121-128

75. Munns DN (1986). Acid soils tolerance in legumes and rhizobia. Adv. Plant Nutr. 2:63-91.

76. Agegnehu G, Yirga C, Erkossa T (2019). Soil acidity management. Ethiopian Institute of Agricultural Research (EIAR). Addis Ababa, Ethiopia. pp. 16-22.

77. Farhoodi A, Coventry DR (2008). Field crop responses to lime in the mid-north region of South Australia. Field Crops Research 108: 45-53.

78. Sanginga N, Woomer PL (2010). Integrated soil fertility management in Africa: principles, practices and developmental process (p.13). Tropical soil biology and fertility Institute of the International Centre for tropical agriculture (TSBF-CIAT), Nairobi, pp. 263.

79. Ferguson BJ, Lin M, Gresshoff PM (2013). Regulation of legume nodulation by acidic growth conditions. Plant Signal Behav 8:e23426.

80. Woomer PL, Martin A, Albrecht A, Resck DVS, Scharpenseel HW (1994). The importance and management of soil organic matter in the tropics. In: Woomer PL, Swift MJ (eds.), The biological Management of Tropical Soil Fertility. Wiley, Chichester. pp. 47-80.

81. White PJ, Broadley MR (2003). Calcium in plants. Ann Bot 92:487-511.

82. Rothwell SA, Elphinstone D, Dodd IC (2015). Liming can decrease legume crop yield and leaf gas exchange by enhancing root to shoot ABA signaling. Journal of Experimental Botany 66 (8): 2335-2345.

83. Lina Y, Yea G, Liua D, Ledgard S, Luoc J, Fana J, Yuana J, Chena Z, Dinga W (2018). Long-term application of lime or pig manure rather than plant residues suppressed diazotroph abundance and diversity and altered community structure in an acidic Ultisol. Soil Biology and Biochemistry 123: 218-228.

84. Muleta D, Maarten HR, Matthew DD (2017). The potential for rhizobial inoculation to increase soybean grain yields on acid soils in Ethiopia. Soil Science and Plant Nutrition 63(5): 441-45.

85. Mitiku G, Mnalku A (2019). Faba bean (Vicia faba L.) yield and yield components as influenced by inoculation with indigenous rhizobial isolates under acidic soil condition of the Central Highlands of Ethiopia. Ethiop. J. Agric. Sci. 29(3):49-61.

86. Farias TP, Trochmann A, Soares BL, Moreira FM (2016). Rhizobia inoculation and liming increase cowpea productivity in Maranhão State. Maringá 38(3):387-395.

87. Bello SK, Yusuf AA, Cargele M (2018). Performance of cowpea as influenced by native strain of rhizobia, lime and phosphorus in Samaru, Nigeria. Symbiosis 75:167-176.

88. Bambara S, Ndakidemi PA (2010). Phaseolus vulgaris response to Rhizobium inoculation, lime and molybdenum in selected low $\mathrm{pH}$ soil in Western Cape, South Africa. African Journal of Agricultural Research 5(14): 1804-1811.

89. Deshwal VK, Pandey P, Kang SC, Maheshwari DK (2003). Rhizobia as biological control agent against soilborn plant pathogenic fungi. Indian Journal of Experimental Biology 41:1160-1164.

90. Sharif T, Khali S, Ahmed S (2003). Effect of Rhizobium sp., on growth of pathogenic fungi under in Vitro conditions. Pakistan Journal of Biological Sciences 6(8):1597-1599.

91. Tamiru G, Muleta D (2018). The Effect of rhizobia isolates against black root rot disease of faba bean (Vicia faba L) caused by Fusarium solani. The Open Agriculture Journal 12:131-147.

92. Al-Ani AR, Adhab MA, Mahdi MH, Abood HM (2012). Rhizobium japonicum as a biocontrol agent of soybean root rot disease caused by Fusarium solani and Macrophomina phaseolina. Plant Protect. Sci. 48(4): 149155.

93. Khan MR, Mohiddin FA, Ahamad F (2017). Inoculant rhizobia suppressed root-knot disease, and enhanced plant productivity and nutrient uptake of some field-grown food legumes. Acta Agriculturae Scandinavica. Section B-Soil and Plant Science 68:166-174

94. Díaz-Valle A, López-Calleja AC, Alvarez-Venegas R (2019). Enhancement of pathogen resistance in common bean plants by inoculation with Rhizobium etli. Front. Plant Sci. 10:1317. 
95. Timmermann T, Armijo G, Donoso R, Seguel A, Holuigue L, González B (2017). Paraburkholderia phytofirmans PsJN protects arabidopsis thaliana against a virulent strain of Pseudomonas syringae through the activation of induced resistance. Mol. Plant Microbe. Interact 30:215-230. 